\title{
Identification and Diagnostic Utility of Serologic Reactive Antigens from Mycobacterium tuberculosis Sonic Extracts
}

\author{
Yu-Mi Kwon', Ki-Hwan Jung ${ }^{2}$, Go-Eun Choi ${ }^{3}$, A-Rum Shin ${ }^{1}$, Byung-Su Lee ${ }^{1}$, Choul-Jae Won', \\ Woo-Sik Kim ${ }^{1}$, Sung-Jae Shin ${ }^{1}$, Jeong-Kyu Park ${ }^{1}$, Chulhun L. Chang ${ }^{3}$ and Hwa-Jung Kim ${ }^{1 *}$ \\ ${ }^{1}$ Department of Microbiology, College of Medicine, Chungnam National University, Deajeon, Korea; \\ ${ }^{2}$ Division of Pulmonary, Sleep and Critical Care Medicine, Department of Internal Medicine, \\ Korea University Ansan Hospital, Ansan, Korea; ${ }^{3}$ Department of Laboratory Medicine, \\ School of Medicine, Pusan National University, Yangsan, Korea
}

It is important to identify and to test serologically active antigens, so as to devise a cocktail of the best antigens or peptides. We searched for antigens that have serodiagnostic utility using two-dimensional fractionation of sonic extracts from Mycobacterium tuberculosis and probing with pools of sera from healthy subjects and patients with tuberculosis (TB). Reactive protein spots with patient sera were identified by tandem mass spectrometry. Three proteins, Rv0652, Rv2626c, and Rv3418c, which have not previously been described as serologic targets, were identified. Rv0652 protein among them was expressed in Escherichia coli and serum IgG antibodies against this antigen were measured in 150 patients with pulmonary TB and in 115 healthy subjects. The sensitivity and specificity were $39 \%$ and $92 \%$, respectively. These results suggest that a newly identified protein, Rv0652 may be a valuable candidate to be included in a cocktail test kit for TB diagnosis.

Key Words: Mycobacterium tuberculosis, Tuberculosis, Tandem mass spectrometry, Rv0652 protein

\section{서 론}

결핵은 결핵균 (Mycobacterium tuberculosis)에 의해 발 생하는 만성감염성 질환으로서, 전 세계인구의 $1 / 3$ 이 감 염되어 있으며 매년 7 8백여만 명의 신환자가 발생하고, 발생률이 매년 $1 \%$ 씩 증가하는 주요 보건질환이다 (1). 이러한 증가는 $\mathrm{AIDS}$ 와 약제내성결핵 문제와 밀접한 연 관이 있다. 일차결핵은 적절한 항결핵제 병합요법으로 비 교적 성공적으로 치유되기 때문에 환자를 조기에 진단하

Received: October 28, 2009/ Revised: November 24, 2009

Accepted: November 30, 2009

*Corresponding author: Hwa-Jung Kim. M.D., Ph.D., Department of Microbiology, College of Medicine, Chungnam National University, 6

Munwha-Dong, Jung-Ku, Daejeon 301-747, Korea

Phone: +82-42-580-8242, Fax: +82-42-585-3686

e-mail: hjukim@cnu.ac.kr

** This work was supported by Chungnam National University Hospital Research Fund, 2007.
여 치료하는 것은 결핵관리의 핵심이라 할 수 있다.

현재 결핵진단은 임상증상 및 도말염색과 배양에 의존 하고 있다. 그러나 acid-fast bacilli (AFB) 도말염색은 빠르 고 간편하지만 민감도가 낮고, 배양은 특이도와 민감도 가 높지만 많은 시간이 걸리기 때문에 조기진단에 부적 합하다. 이러한 이유로 결핵조기 진단을 위한 다양한 방 법들이 연구되어 왔다 (2). PCR과 같은 분자생물학적인 방법은 민감도가 높고 균종까지 감별할 수 있지만 비용 이 많이 들기 때문에 다수를 대상으로 하는 검진에는 적 합하지 않다. 결핵 특이항원으로 말초혈액단핵세포를 자 극하여 생산되는 IFN- $\gamma$ 를 측정하는 방법은 결핵발생이 적은 지역에서는 잠복결핵 진단에 효과적인 방법이지만 비용이 많이 들고 결핵발생률이 높은 나라에서는 유용 성이 떨어진다 (3). 임상검체에서 항체를 측정하는 혈청 학적인 방법은 간단하고 경제적이며 쉽게 어디서나 할 수 있다는 장점이 있다. 이 방법은 또한 폐외결핵이나 객담을 잘 얻을 수 없는 소아결핵 진단에 적합하다. 그 
러나 많은 노력에도 불구하고 임상에서 적용될 수 있는 특이도와 민감도를 가진 혈청학적인 결핵진단법이 개발 되어 있지 않다. 근본적인 장애요인은 개인 간 그리고 질환 병기에 따른 항체반응의 다양성 때문이다 $(4,5)$. 따 라서 단일항원 대신 유의성이 있는 진단항원들을 조합 한 칵테일 항원을 사용하여 민감도를 높이려는 연구가 진행되고 있다 (6 8).

혈청학적 결핵진단법 개발을 위해서는 진단적인 유의 성이 높은 항원 즉, 건강인에서는 반응하지 않고 결핵환 자에서만 반응하는 항원을 탐색하는 것이 가장 핵심적인 과제이다. 그 동안 많은 연구자들은 유의성이 높은 여러 항원을 보고하여 왔지만 (2), 혈청학적인 반응성이 강한 새로운 항원 동정이 지속적으로 필요하다는 사실은 널리 인정되고 있다. 결핵균에서 분비되는 단백들이 면역계에 의해 인식되기 때문에 많은 연구자들은 주로 결핵균 배 양액으로부터 아단위 백신 또는 면역진단항원을 탐색하 여 왔다 (9 11). 결핵균의 세포질 항원에도 다수의 후보 항원이 존재할 것으로 생각되지만 이에 대한 연구는 상 대적으로 적다. 실제 16-kDa HspX ( $\alpha$-crystalline)은 세포질 항원이며, 정지기나 저산소 조건에서 발현이 증가되는 단 백으로써 진단적인 유의성이 있으며 상품화된 키트에 사 용되고 있는 항원 중의 하나이다 $(12,13)$. 또한 결핵균체 추출액에는 세포질 항원, 세포막 항원 그리고 일부 분비 항원들이 존재하기 때문에 본 연구에서는 이들 추출항원 으로부터 강한 항체반응을 나타내는 3 개의 새로운 단백 을 동정하고, 이중 Rv0652 단백을 유전자재조합단백으로 제조하여 결핵에 대한 혈청학적 진단적 가치를 평가하 였다.

\section{재료 및 방법}

\section{혈청}

폐결핵환자와 건강인 총 256 명의 혈청을 본 연구에 사 용하였다. 결핵환자 혈청은 고려대 안산병원 (안산, 경기 도)에 내원하여 폐결핵으로 진단받은 환자로부터 치료 전 또는 치료개시 2 주 내에 얻었다. 폐결핵은 임상증상, 객담도말 염색과 배양 및 흥부 X-선 사진으로 진단하였 으며, 환자는 객담도말 양성 또는 배양 양성인을 포함하 는 AFB 양성군 (101명)과 도말과 배양 모두 음성인 AFB 음성군 (49명)으로 구분하였다. 건강인은 결핵을 않은 경 험이 없는 충남대학교 의학과 학생 115 명을 대상으로 하
였다. 대상인 모두 당뇨병이 없었고 스테로이드를 치료받 은 환자도 없었으며 모두 HIV 음성이었다. 본 연구는 고려대 안산병원 생명윤리위원회로부터 승인을 얻었으 며, 모든 환자로부터 혈청 제공 동의서를 받았다.

\section{결핵균 배양과 균체 추출액}

결핵균 (M. tuberculosis H37Rv, ATCC 27294)은 Sauton 배지에 $37^{\circ} \mathrm{C}, 5 \sim 6$ 주간 표면 배양하여 균체를 수집하였 다. 균체로부터 단백질 추출은 $10 \mathrm{mM} \mathrm{KPB}$ (potassium phosphate buffer, $\mathrm{pH}$ 7.0)로 1회 세척하고, $1 \mathrm{mM}$ PMSF와 $1 \mathrm{mM} \mathrm{EDTA}$ 가 첨가된 $10 \mathrm{mM} \mathrm{KPB}$ 로 부유하여 얼음위 에서 초음파 (sonication, pulse on-5sec/off-5sec; 온도 $4^{\circ} \mathrm{C}$; 진폭 $30 \%$ )로 30 분 동안 파쇄하였다. 세포를 용해시킨 후 $4^{\circ} \mathrm{C}$ 에서 $22,000 \mathrm{rpm}$ 으로 30 분 동안 원심분리하여 파쇄 되지 않은 균체를 제거하고 상층액은 $0.45 \mu \mathrm{m}$ filter membrane (Millipore, Billerica, MA, USA)으로 1차 여과하 고, $0.2 \mu \mathrm{m}$ filter로 2 차 여과멸균하였다. 여과된 추출액에 ammonium sulfate가 $5 \%$ 농도가 되게 천천히 첨가한 후 $20,000 \mathrm{rpm}$ 에서 30 분 동안 원심분리하여 불필요한 성분 을 침전시켰다. 상층액에 다시 ammonium sulfate 농도가 $85 \%$ 가 되도록 천천히 첨가한 후 $20,000 \mathrm{rpm}$ 에서 30 분 동 안 원심분리하였다. 침전된 단백 pellet은 $10 \mathrm{mM} \mathrm{NaCl}$ 이 첨가된 $20 \mathrm{mM}$ Tris- $\mathrm{HCl}(\mathrm{pH}$ 7.4) buffer로 부유시킨 후 투 석하고 $-70^{\circ} \mathrm{C}$ 에 보관하였다.

\section{단백질의 농도 측정}

단백질의 농도는 bovine serum albumin (BSA)를 표준으 로 하여 Micro BCA protein assay kit (Pierce, Rockford, IL, USA)를 이용하여 Bradford method로 측정하였다.

\section{SDS-PAGE와 immunoblotting}

단백질 분석을 위한 SDS-PAGE는 $15 \%$ polyacrylamide 를 사용하여 Laemmli (14)의 discontinuous buffer system에 준하여 실시하였고, 전기영동 후 Coomassie blue로 염색 하여 관찰하였다.

Immunoblotting은 Shin 등 (8)의 방법에 준하여 실시하 였다. 약술하면 전기영동으로 분리된 단백질은 nitrocellulose membrane에 전사한 후에 5\% skim milk가 포함 된 phosphate buffered saline (PBS)로 blocking하였다. 혈청 을 100 200배 희석 후 $37^{\circ} \mathrm{C}$ 에서 1시간 반응시켰다. 2 차 항체는 horseradish peroxidase (HRP)-conjugated anti-human 
$\operatorname{IgG}$ (Sigma-Aldrich, St. Louis, MO, USA)를 3,000배 희석하 여 사용하였다.

2-차원 전기영동 (2-dimensional electrophoresis; 2$\mathrm{DE})$ 과 단백 동정

2-DE는 pH 4 7의 IPG strip (Bio-Rad, Hercules, CA, USA)을 사용하여 Lee 등 (15)의 방법에 준하여 isoelectric focusing을 실시한 후 2차원은 SDS-PAGE로 단백을 분리 하고 겔은 Coomassie blue로 염색하거나 immunoblotting 으로 분석하였다.

단백의 동정은 2-DE 후 Coomassie blue로 염색한 겔에 서 유의성이 있는 spot을 Yonsei Proteomic Research Center (Seoul, Korea)에 의뢰하여 LC-MS/MS로 동정하였다.

\section{결핵균체 추출액의 일차 분획화}

결핵균체 추출액의 $85 \%$ ammonium sulfate 분획은 10 $\mathrm{mM} \mathrm{NaCl}$ 이 첨가된 $20 \mathrm{mM}$ Tris- $\mathrm{HCl}(\mathrm{pH}$ 7.4) buffer로 평 형시킨 DEAE-Sepharose column에 통과시켰다. 동일한 buffer로 충분히 세척한 후에 흡착된 단백질은 $10 \mathrm{mM}$ 부 터 $0.5 \mathrm{M} \mathrm{NaCl}$ 까지 salt gradient로 용출하였다. 각 분획의 단백은 SDS-PAGE를 통해 확인하였다. 유의성이 있는 $15-\mathrm{kDa}$ 단백 band가 포함된 분획을 모아 농축하고 $\mathrm{PBS}$ 에 투석하고 전기영동과 immunoblotting으로 분석하였다.

\section{유전자재조합단백질 발현 및 정제}

결핵균 genomic DNA로부터 Rv0652 유전자를 증폭하 기 위한 primer의 forward 쪽에는 BamH I, reverse 쪽에는 EcoRI 제한효소 site를 넣었다. Forward primer의 sequence 는 5'-GGATCCATGGCAAAGCTC-3'이고, reverse primer 는 5'-GAATTCCTTGACGGT-3'이었다. PCR 유전자 산물 을 T-벡터 (Promega, Madison, WI, USA)에 클로닝한 후 $\mathrm{BamH} 1$ 과 EcoRI으로 절단한 후, 발현벡터인 $\mathrm{pET} 28 \mathrm{a}$ 에 삽입하였다.

$\mathrm{Rv} 0652$ 유전자가 삽입된 $\mathrm{pET} 28 \mathrm{a}$ 벡터를 형질전환시 킨 E. coli BL-21를 $600 \mathrm{~nm}$ 에서의 흡광도 (optical density; $\mathrm{OD}$ )가 0.4 0.6까지 이르도록 배양한 후에 isopropyl-Dthiogalactopyranoside (IPTG)를 $1 \mathrm{mM}$ 농도로 첨가하여 하룻밤 동안 배양하여 단백질 발현을 유도하였다. 발현 된 단백질은 nickel-nitrilotriacetic acid (Ni-NTA, Invitrogen, Carlsbad, CA, USA) agarose를 이용하여 제조사의 방법 에 준하여 정제하였다. 최종적으로 정제한 재조합단백은
SDS-PAGE로 분석하였다.

\section{ELISA (Enzyme-linked immunosorbent assay)}

Rv0652 단백질에 대한 항체가는 Shin 등 (8)의 방법에 준하여 ELISA로 측정하였다. 약술하면 96-well microplate (Nunc, Roskilde, Denmark)에 각 well당 단백을 $100 \mathrm{ng}$ 씩 분주하여 $4{ }^{\circ} \mathrm{C}$ 에서 하룻밤 coating하였다. Plate는 $3 \% \mathrm{BSA} /$ $\mathrm{PBS} /$ Tween 20 (PBST)으로 blocking을 실시하였고, 혈청 은 blocking buffer에 1;200으로 희석하여 각 well당 0.1 $\mathrm{ml}$ 씩 분주하여 반응시켰고, 2차항체는 1:9,000으로 희석 된 HRP-conjugated anti-human $\mathrm{IgG}$ 를 well당 $0.1 \mathrm{ml}$ 씩 분 주하여 반응시켰다. 발색반응은 $0.5 \% \quad \mathrm{H}_{2} \mathrm{O}_{2}$ 가 첨가된 tetramethylbenzidine (Sigma) 용액을 첨가하여 5분간 반 응 후 $1 \mathrm{~N} \mathrm{H}_{2} \mathrm{SO}_{4}$ 을 첨가하여 반응을 정지시켰다. $\mathrm{OD}$ 는 $450 \mathrm{~nm}$ 에서 ELISA microplate reader (Molecular Devices, Sunnyvale, CA, USA)로 측정하였다.

\section{통계 분석}

항체가의 양성과 음성을 구분하기 위해서 cutoff 값을 receiver operator characteristic (ROC) curve 분석을 통해 얻었다. 검사결과의 정확성을 측정하기 위해 area under the ROC curve (AUC) 값을 계산하였다. 결핵환자와 건강 인 혈청의 평균 흡광도간의 통계학적인 유의성 차이는 Mann-Whitney test로 평가하였다. 통계 분석은 MedCalc statistical software를 사용하였다.

결 과

결핵균체 추출항원의 혈청학적인 분석과 항원 동정

결핵균체 추출액을 전기영동으로 분석한 결과 분자량 $27-\mathrm{kDa}$ 이상에서 많은 항원 band가 밀집되어 관찰되었다 (Fig. 1A). 분리된 단백질을 nitrocellulose membrane에 전 사한 후에 $5 \mathrm{~mm}$ 간격으로 잘라 개개의 결핵환자 (18명) 와 건강인 (20명) 혈청에서 항체반응양상을 분석하였다. 다른 보고와 동일하게 개인 간 항체반응의 다양성을 확 인할 수 있었다 (Fig. 1B와 1C). 다수의 항원에 반응하는 사람부터 환자임에도 거의 반응하지 않는 사람이 있었다. 이는 단일항원으로는 민감도를 만족시킬 수 없다는 사실 을 증명하는 것이다. 환자군에서 분자량 $27-\mathrm{kD}$ 와 $47-\mathrm{kDa}$ 사이에 해당되는 항원들이 집중적으로 강한 항체반응을 나타내었다. 건강인과 환자군에서 $37-\mathrm{kDa}$ 분자 부위에 뚜 
렷한 band를 나타내지 않고 밀집된 반응을 나타내는 이 유는 추출액에 존재하는 당지질 성분에 의한 것으로 생 각된다. $19-\mathrm{kDa}$ 이하에 존재하는 몇 개의 항원이 특이적 으로 환자에서만 반응하였다. 특히 $15-\mathrm{kDa}$ 항원 band는


Figure 1. SDS-PAGE and immunoblot analysis of $M$. tuberculosis sonic extracts. Total protein was extracted from $M$. tuberculosis and subjected to SDS-PAGE. The gels were analyzed by Coomassie blue (A) and immunoblotting with individual tuberculosis (TB) patient sera (B) and healthy control (HC) sera (C). The sera were diluted to $1: 100$.
건강인에서 한 명만이 반응했기 때문에 진단적인 유의성 이 있을 것으로 생각되었다.

이들 $15-\mathrm{kDa}$ 주위의 항원을 동정하기 위해 2-DE와 immunoblot을 시행하였다 (Fig. 2). 무작위로 결핵환자 혈 청 7 개와 건강인의 혈청 7 개를 각각 모은 혈청을 분석에 사용하였다. 분자량 $19-\mathrm{kDa}$ 이하에서 환자 혈청하고만 반응하는 6개의 뚜렷한 spot이 관찰되었으며 (Fig. 2B), 이들 6개의 spot을 LC-MS/MS로 동정하였다. 그러나 1 번 spot은 양적으로 적어 동정되지 않았기 때문에 균체 추출액을 ion-exchange chromatography로 일차 분획화를 실시하였다. 일반적으로 일차 분획화의 장점은 미량으로 존재하는 단백들이 농축되는 결과를 얻을 수 있다. 각각 의 chromatography 분획을 SDS-PAGE로 분석하여 1 번 spot이 존재하는 분획을 모아 농축하였고, 다시 2-DE와 immunoblot으로 분석하였다 (Fig. 3). 일차 분획화로 정제 된 분획에서 $15-\mathrm{kDa}$ 항원 band를 SDS-PAGE로 확인할 수 있었고, 이들 band는 환자 혈청하고만 반응하였다 (Fig. $3 \mathrm{~A}$ 에 화살표로 표기). 2-DE로 분리한 후에 1 번 spot의 단백 동정을 다시 실시하였다 (Fig. 3B와 3C).

6 개의 spot을 동정한 결과는 Table 1 과 같다. 2 번과 5 번 spot은 동일한 단백으로 HspX이었고, 3번 spot은 CFP-10 단백으로 이들 두 개의 단백은 이미 혈청학적인 연구가 보고된 항원이다 (5). 다른 3종류의 단백은 Rv0652, Rv$2626 \mathrm{c}$ 와 Rv3418c (GroES)로서 혈청학적 반응성에 대한



B



Figure 2. 2-DE analysis of sonic extracts of $M$. tuberculosis. The extract proteins $(300 \mu \mathrm{g})$ were separated by isoelectric focusing using a 7-cm $\mathrm{pH}$ gradient strip ( $\mathrm{pH} 4$ to 7 ) in the first dimension and 15\% SDS-PAGE in the second dimension. The gels were stained with Coomassie blue (A) and immunoblotting using pooled sera from TB patients and healthy controls (B). The sera were diluted to 1:100. Indicated spots of panel A were seroreactvie proteins. 
연구 보고가 없는 항원으로 본 연구에서 처음 보고하였다.

\section{Rv0652 단백질의 발현과 진단적인 유의성}

결핵균체 추출항원에서 혈청학적 반응성이 확인된 항 원 Rv0652 (ribosomal protein L7/L12) 단백을 유전자재조 합기술을 이용하여 대장균에서 발현하여 정제하였다. 정 제된 재조합단백질은 SDS-PAGE 분석에서 약간의 오염

A

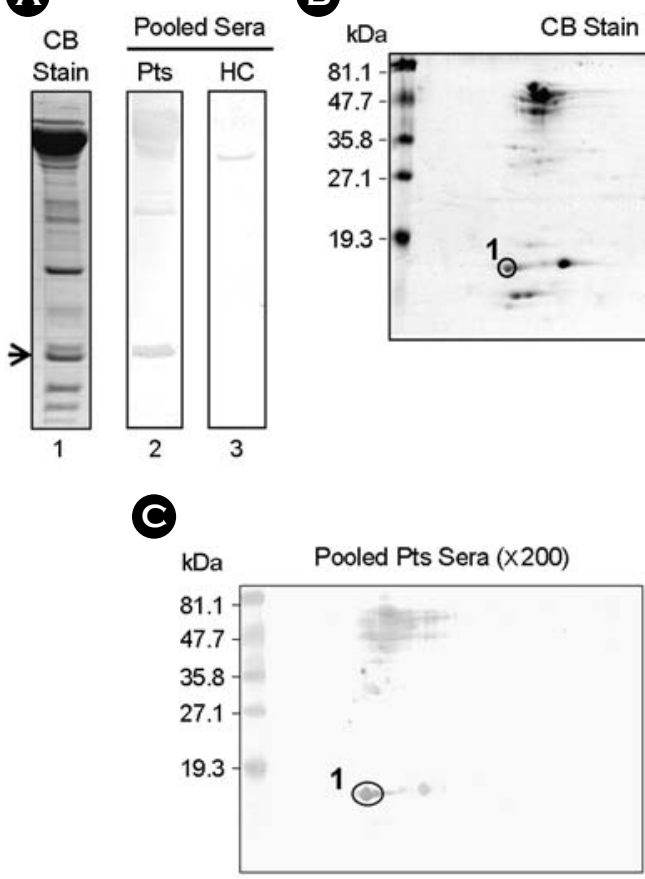

Figure 3. Partial purification and immunoblot analysis of 15$\mathrm{kDa}$ protein from $M$. tuberculosis sonic extracts. The extracts were fractionated using DEAE-Sepharose chromatography. Fractions containing 15-kDa proteins were pooled, subjected to SDS-PAGE, and analyzed by Coomassie blue staining and immunoblotting (A). Partially purified protein was also separated by 2-DE and then analyzed by Coomassie blue staining (B) and immunoblotting (C).
된 band가 관찰되었지만 항체반응을 측정할 수준인 $95 \%$ 이상의 순도를 나타내었다 (Fig. 4A).

결핵환자와 건강인의 혈청에서 Rv0652 단백에 대한 $\mathrm{IgG}$ 항체가를 ELISA로 측정하였다. 환자군의 Rv0652 단 백에 대한 항체가는 건강인에 비해 유의하게 높았다 ( $p$ $<0.05$ ) (Table 2). 그러나 AFB 양성 환자군과 음성 환자 군사이에는 뚜렷한 차이는 없었다. ROC curve 분석에서 $\mathrm{AUC}$ 값은 1 에 근접할수록 진단적인 유의성이 높다는 것 을 나타내는데, Rv0652의 AUC 값은 0.57로 진단적인 유 의성이 높지 않았다. ROC curve상에서 최대의 정확도를 나타낼 때의 흡광도 값인 0.37 을 cutoff 값으로 정하여 분 석하였다. Fig. $4 \mathrm{~B}$ 와 같이 각 혈청의 항체가 분포도를 보 면 넓은 범위로 퍼져서 분포함을 알 수 있었고, Rv0652

A

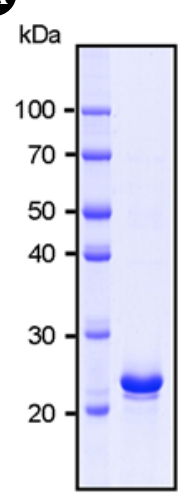

B

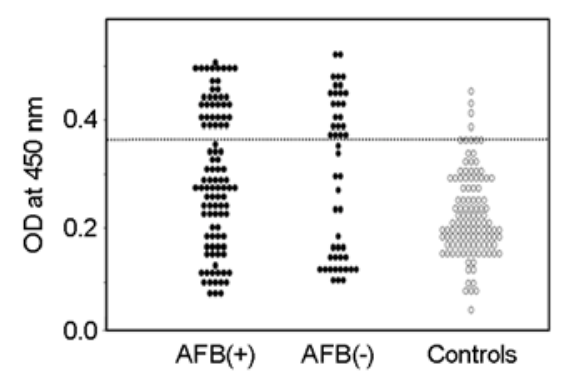

Figure 4. SDS-PAGE analysis and seroreactivity of the recombinant Rv0652 proteins. (A) The protein was expressed in E. coli, purified by Ni-NTA affinity chromatography, and subjected to SDS-PAGE. The gel was stained with Coomassie blue. (B) IgG antibody responses to purified Rv0652 were determined by ELISA in AFB-positive and AFB-negative groups of patients with pulmonary TB and healthy controls. The horizontal line in panel represents the cut-off value determined at the maximal accuracy on the ROC curve.

Table 1. The identification of seroreactive proteins from M. tuberculosis-sonic extracts

\begin{tabular}{|c|c|c|c|c|}
\hline Spot no. & Protein (Gene number or name) & Score & Nominal mass & Calculated pI \\
\hline 1 & Ribosomal protein L7/L12 (Rv0652, rplL) & 93 & 13,440 & 4.30 \\
\hline 2 & $\alpha$-crystalline, $\mathrm{MMP}^{a}(R v 2031 c, H s p X$, acr $)$ & 101 & 16,086 & 5.0 \\
\hline 3 & CFP-10 (Rv3874, ,esxB) & 103 & 10,696 & 4.45 \\
\hline 4 & Conserved hypothetical protein (Rv2626c) & 45 & 15517 & 4.77 \\
\hline 5 & $\alpha$-crystalline, MMP (Rv2031c, HspX, acr) & 58 & 16,086 & 5.0 \\
\hline 6 & 10-kDa Chaperonin GroES (Rv3418c, groES) & 112 & 10,667 & 4.62 \\
\hline
\end{tabular}

\footnotetext{
${ }^{a}$ MMP: major membrane protein
} 
Table 2. Sensitivity and specificity of Rv0652 antigen

\begin{tabular}{|c|c|c|c|c|}
\hline Patient group (no. of subjects) & Mean $\mathrm{OD} \pm \mathrm{SD}^{a}$ & No. of positive individuals ${ }^{b}$ & Sensitivity (\%) & Specificity (\%) \\
\hline \multicolumn{5}{|l|}{ Pulmonary TB } \\
\hline AFB-positive $(101)^{c}$ & $0.29 \pm 0.13^{*}$ & 35 & 34.7 & \\
\hline AFB-negative (49) ${ }^{d}$ & $0.30 \pm 0.15^{*}$ & 23 & 46.9 & \\
\hline Total (150) & $0.30 \pm 0.13^{*}$ & 58 & 39.0 & \\
\hline Healthy Control (115) & $0.23 \pm 0.08^{\#}$ & 9 & & 92.2 \\
\hline \multicolumn{5}{|c|}{$\begin{array}{l}{ }^{a} \text { Mann-Whitney } U \text {-test for multiple comparisons of means was used to determine whethe } \\
\text { results for the three groups. The different symbols }(*, \#) \text { indicate significant difference }(p \\
\text { for the three groups. } \\
{ }^{b} \text { The cut-off value was determined when the accuracy was maximal on the ROC curve. } \\
{ }^{c} \text { AFB-positive group consisted of smear-positive and/or culture-positive patients. } \\
{ }^{d} \text { AFB-negative group consisted of smear and culture-negative patients }\end{array}$} \\
\hline
\end{tabular}

단백의 민감도는 $\mathrm{AFB}$ 양성 환자군에서 $35 \%, \mathrm{AFB}$ 음성 환자군에서는 $47 \%$, 전체적으로 $39 \%$ 를 나타내었다. 특이 도는 $92 \%$ 를 나타내었다.

\section{고 찰}

결핵균은 복잡한 항원구조와 다양한 면역학적인 활성 을 나타내는 면역성분들을 포함하고 있다. 혈청학적 진단 용 항원뿐만 아니라 T-림프구 자극항원, 아단위 백신 후 보항원 등이 결핵균 배양액 및 균체항원에서 동정되고 있다 (11). 본 연구에서는 결핵균 배양액에 비해 연구가 상대적으로 미흡한 균체추출항원을 2-DE와 immunoblot 으로 분석하여 항체반응을 강하게 유도하는 항원을 동정 한 결과 총 6 개의 단백항원을 동정할 수 있었다. 혈청학 적인 연구가 보고되지 않은 3 종류의 단백을 새로 확인하 였다. 이들 중 Rv0652 단백에 대한 재조합단백질을 제조 하여 혈청학적인 유의성을 평가한 결과 기대만큼의 민감 도는 얻을 수 없었다.

$\mathrm{HspX}$ 는 주요 세포막단백으로써 (16), 저산소 조건에서 발현이 증가되는 단백으로, 혈청학적 진단을 위한 민감 도는 보고자에 따라 32 75\%였다 $(5,12,13)$. 또한 상품 화된 혈청학적 진단키트인 Pathozyme TB complex에 포 함된 항원성분 중의 하나이다. 본 연구에서 2 번과 5 번 spot은 모두 $\mathrm{HspX}$ 로 동정되었는데 (Fig. 2), 동일한 단백 임에 불구하고 분자량이 약간 차이가 나는 이유는 단백 질 분리시 약간 변성되었거나 post-translational modification 때문일 것으로 생각된다 (2). CFP-10은 M. bovis BCG 균
주에는 없는 단백으로, 잠복결핵진단키트 (QuantiFeron$\mathrm{TB}$ )에 사용되는 주요 T-세포 자극항원이다 (11). CFP-10 의 혈청학적 진단을 위한 민감도는 $29 \sim 60 \%$ 이다 (5). $\mathrm{Rv} 2626 \mathrm{c}$ 는 hypothetical protein으로 혈청학적인 항원으로 본 연구에서 처음 동정하였다. Rv3418는 heat shock protein 으로 여러 가지 스트레스 조건에 반응하는 단백이며 또 한 결핵환자에서 $\mathrm{T}$-세포 자극항원으로 보고된 바 있다 (17). Rv0652 단백은 50S ribosomal protein L7/L12이다 (18). L7과 $\mathrm{L} 12$ 을 코딩하는 유전자는 Rv0652(rplL)로써 L7의 아미노말단부위가 acetylation된 것을 제외하고는 동일한 단백이다. 특히 이 단백은 우리나라에서 흔히 분리되는 임상균주인 $\mathrm{K}$-균주의 배양액에는 표준균주에 비해 비교 적 풍부히 존재하는 단백이다 (19). Ribosomal protein들은 중요한 면역기능을 담당하는 것으로 알려져 있다 (20). 따라서 일차적으로 Rv0652 단백을 선택하여 재조합단백 질을 제조하여 혈청학적 진단적인 유의성을 평가하였다.

$\mathrm{Rv} 0652$ 단백의 계산된 분자량은 $13.4-\mathrm{kDa}$ 이지만 실 제 native 단백은 $15-\mathrm{kDa}$ 이며 대장균에서 발현된 단백은 $22-\mathrm{kDa}$ 정도였다. 이는 다른 보고에서처럼 재조합단백으 로 발현되는 경우 poly His이 부착되어 분자량이 증가된 것으로 생각된다 (8). Figure 1에서 결핵환자 혈청의 $50 \%$ 는 $15-\mathrm{kDa}$ 에 해당되는 band에 반응하였다. 2-DE 분석 상 $\mathrm{Rv} 0652$ 는 HspX의 spot과 동일한 위치에 있기 때문에 이 들 중 하나의 단백에 반응해도 일차원적인 전기영동과 immunoblot에서는 모두 양성으로 나올 수 있다. 따라서 ELISA 분석에서 Rv0652의 민감도가 기대한 것 보다 낮 은 $39 \%$ 를 나타낸 것으로 생각된다. 또한 민감도와 특이 
도는 cutoff 값을 어떻게 결정하느냐에 따라 좌우된다. 보통은 건강인의 항체가 평균에 3 배의 표준편차를 더한 값을 cutoff 값으로 정하게 된다. 최근에는 cutoff 값을 $\mathrm{ROC}$ curve에서 가장 높은 정확도를 나타낼 때의 값으로 정하기도 한다 $(8,21)$. 두 경우 모두 cutoff 값은 건강대 조군의 항체가에 좌우된다. 본 연구에서는 건강인 혈청 에서도 Rv0652에 대한 항체반응이 비교적 높기 때문에 민감도가 낮았다. 건강인 혈청에서 항체가가 높은 이유 로는 immunoblot 분석에서 인식되지 않는 conformational epitope이 ELISA 분석에서는 인식되기 때문에 이들 epitope이 건강인의 혈청에 존재하는 항체와 교차반응 을 할 수 있다. 또한 Rv0652는 다른 세균에 존재하는 ribosomal protein L7/L12 단백과의 항원적인 유사성에 의 해서도 교차반응이 나타날 수 있다. 또 다른 가능성은 $\mathrm{Rv} 0652$ 단백이 M. bovis에도 존재하기 때문에 $\mathrm{BCG}$ 접 종 양성 건강인뿐만 아니라 잠복결핵감염자인 PPD 양 성인에서도 Rv0652 단백에 대한 항체가가 높을 가능성 이 있다. 따라서 Rv0652로부터 진단적인 유의성이 높은 peptide만을 동정하여 사용하면 교차반응하는 epitope을 배제할 수 있기 때문에 더 좋은 결과를 얻으리라 생각 된다.

혈청학적인 연구들을 분석해보면 대부분 항원의 민감 도는 $\mathrm{AFB}$ 음성군 보다 양성군에서 민감도가 높은 편이 다 $(5,11)$. 대표적인 예로 $38-\mathrm{kDa}$ 항원의 민감도는 $\mathrm{AFB}$ 양성군에서 음성군에 비해 유의하게 높다고 알려져 있다. 그러나 $\mathrm{HspX}$ 의 민감도는 음성 환자군에서 높다 $(2,11)$. 이유를 정확하게 설명할 수 없지만, $\mathrm{HspX}$ 는 대수증식기 에는 발현되지 않고 주로 제자리성장기 때 발현이 되기 때문이라고 생각된다 (12). 본 연구에서도 Rv0652 단백 의 민감도는 $\mathrm{AFB}$ 양성군보다 $\mathrm{AFB}$ 음성군에서 더 높았 다. 이는 Rv0652 단백은 세포질 항원이기 때문에 초기 보다는 질병이 진행되거나 면역반응에 의해 결핵균들이 제거되는 시점에서 항원이 면역계에 노출되기 때문이라 고 생각된다.

혈청학적인 진단법 개발 연구에서 가장 큰 장애요인은 항체반응의 다양성이다. 본 연구에서 개개인의 혈청 모두 를 2-DE로 분석할 수 없기 때문에 몇 명의 환자혈청을 모아서 분석하였지만, 이 중 하나의 혈청만 강하게 반 응해도 양성으로 판단될 수 있는 단점이 있다. 또 다른 장애요인은 결핵균 항원계의 복잡성이다. 본 연구에서 도 균체 추출액 전체를 2-DE로 분리할 경우 1 번 spot인
Rv0652를 동정할 수 없었고 일차 분획화로 부분 정제한 후에 동정할 수 있었다. 최근 결핵균 단백질을 다단계 분 획화로 960 개의 분획으로 나눈 후에, microarray로 항체 반응을 분석하여 4종류의 새로운 B-세포 항원을 보고한 바 있다 (22). 따라서 항원의 분획화를 통해 분석하면 보 다 많은 단백을 동정할 수 있을 것이다.

주요 항원을 조합한 혼합항원의 진단적인 유용성과 높 은 면역원성을 나타내는 항원의 peptide를 이용한 진단법 의 유용성이 보고되고 (23) 있기 때문에, 본 연구에서 동 정된 단백들은 이러한 연구의 중요한 후보항원이 될 것 으로 생각된다.

\section{참 고 문 헌}

1) World Health Orgnaization. Global Tuberculosis ControlSurveilance, Planning, Financing, WHO report 2005, Wolrd Health Organization, Geneva.

2) Abebe F, Holm-Hansen C, Wiker HG, Bjune G. Progress in serodiagnosis of Mycobacterium tuberculosis infection. Scand J Immunol 2007;66:176-91.

3) Pai M, Kalantri S, Dheda K. New tools and emerging technologies for the diagnosis of tuberculosis: Part I. Latent tuberculosis. Expert Rev Mol Diagn 2006;6:413-22.

4) Lyashchenko K, Colangeli R, Houde M, Al Jahdali H, Menzies D, Gennaro ML. Heterogeneous antibody responses in tuberculosis. Infect Immun 1998;66:3936-40.

5) Steingart KR, Dendukuri N, Henry M, Schiller I, Nahid P, Hopewell PC, Ramsay A, Pai M, Laal S. Performance of purified antigens for serodiagnosis of pulmonary tuberculosis: a meta-analysis. Clin Vaccine Immunol 2009;16:260-76.

6) Houghton RL, Lodes MJ, Dillon DC, Reynolds LD, Day CH, McNeill PD, Hendrickson RC, Skeiky YA, Sampaio DP, Badaro R, Lyashchenko KP, Reed SG. Use of multiepitope polyproteins in serodiagnosis of active tuberculosis. Clin Diagn Lab Immunol 2002;9:883-91.

7) Zhang SL, Zhao JW, Sun ZQ, Yang EZ, Yan JH, Zhao Q, Zhang GL, Zhang HM, Qi YM, Wang HH, Sun QW. Development and evaluation of a novel multiple-antigen ELISA for serodiagnosis of tuberculosis. Tuberculosis 2009; 89:278-84.

8) Shin AR, Shin SJ, Lee KS, Eom SH, Lee SS, Lee BS, Lee JS, Cho SN, Kim HJ. Improved sensitivity of diagnosis of tuberculosis in patients in Korea via a cocktail enzyme-linked 
immunosorbent assay containing the abundantly expressed antigens of the K strain of Mycobacterium tuberculosis. Clin Vaccine Immunol 2008;15:1788-95.

9) Malen H, Softeland T, Wiker HG. Antigen analysis of Mycobacterium tuberculosis $\mathrm{H} 37 \mathrm{Rv}$ culture filtrate proteins. Scand J Immunol 2008;67:245-52.

10) Ben Amor Y, Shashkina E, Johnson S, Bifani PJ, Kurepina N, Kreiswirth B, Bhattacharya S, Spencer J, Rendon A, Catanzaro A, Gennaro ML. Immunological characterization of novel secreted antigens of Mycobacterium tuberculosis. Scand J Immunol 2005;61:139-46.

11) Laal S, Skeiky YA. Immune-based methods, In: Cole ST, Eisenach KD, McMurray DN, Jacobs WR Jr, editors. Tuberculosis and the Tubercle Bacillus. Washington, D.C.: American Society for Microbiology Press; 2005. p.71-83.

12) Yuan Y, Crane DD, Simpson RM, Zhu YQ, Hickey MJ, Sherman DR, Barry CE 3rd. The 16-kDa alpha-crystallin (Acr) protein of Mycobacterium tuberculosis is required for growth in macrophages. Proc Natl Acad Sci USA 1998;95: 9578-83.

13) Raja A, Uma Devi KR, Ramalingam B, Brennan PJ. Immunoglobulin $\mathrm{G}, \mathrm{A}$, and $\mathrm{M}$ responses in serum and circulating immune complexes elicited by the 16-kilodalton antigen of Mycobacterium tuberculosis. Clin Diagn Lab Immunol 2002; 9:308-12.

14) Laemmli UK. Cleavage of structural proteins during the assembly of the head of bacteriophage T4. Nature 1970;227: 680-5.

15) Lee KS, Park JK, Lim JH, Kim SY, Shin AR, Yang CS, Oh JH, Kwon YM, Song CH, Jo EK, Kim HJ. Identification of proteins induced at hypoxic and low $\mathrm{pH}$ conditions in Mycobacterium tuberculosis H37Rv. J Bacteriol Virol 2006;36:59-68.

16) Lee BY, Hefta SA, Brennan PJ. Characterization of the major membrane protein of virulent Mycobacterium tuberculosis. Infect Immun 1992;60:2066-74.

17) Chua-Intra B, Wilkinson RJ, Ivanyi J. Selective T-cell recognition of the N-terminal peptide of GroES in tuberculosis. Infect Immun 2002;70:1645-7.

18) Camus JC, Pryor MJ, Medigue C, Cole ST. Re-annotation of the genome sequence of Mycobacterium tuberculosis H37Rv. Microbiology 2002;148:2967-73.

19) BahK YY, Kim SA, Kim JS, Euh HJ, Bai GH, Cho SN, Kim YS. Antigens secreted from Mycobacterium tuberculosis: identification by proteomics approach and test for diagnostic marker. Proteomics 2004;4:3299-307.

20) Gregory RL. Microbial ribosomal vaccines. Rev Infect Dis 1986;8:208-17.

21) Rosenkrands I, Aagaard C, Weldingh K, Brock I, Dziegiel MH, Singh M, Hoff S, Ravn P, Andersen P. Identification of Rv0222 from RD4 as a novel serodiagnostic target for tuberculosis. Tuberculosis 2008;88:335-43.

22) Sartain MJ, Slayden RA, Singh KK, Laal S, Belisle JT. Disease state differentiation and identification of tuberculosis biomarkers via native antigen array profiling. Mol Cell Proteomics 2006;5:2102-13.

23) Singh KK, Sharma N, Vargas D, Liu Z, Belisle JT, Potharaju V, Wanchu A, Behera D, Laal S. Peptides of a novel Mycobacterium tuberculosis-specific cell wall protein for immunodiagnosis of tuberculosis. J Infect Dis 2009;200:57181. 